\title{
Control of Potato Tuber Rots Caused by Oomycetes with Foliar Applications of Phosphorous Acid
}

\author{
Dennis A. Johnson, Department of Plant Pathology, Washington State University (WSU), Pullman 99164-6430; \\ Debra A. Inglis, WSU-Mount Vernon Research \& Extension Unit, Mount Vernon 98273-4768; and Jeffrey S. \\ Miller, University of Idaho, Aberdeen Research and Extension Center, Aberdeen 83210
}

\begin{abstract}
Johnson, D. A., Inglis, D. A., and Miller, J. S. 2004. Control of potato tuber rots caused by oomycetes with foliar applications of phosphorous acid. Plant Dis. 88:1153-1159.

Phosphorous acid for control of tuber rots caused by Phytophthora infestans, P. erythroseptica, and Pythium ultimum was applied to foliage of potato cultivars at various application timings and rates under growing conditions in the Pacific Northwest at Othello and Mount Vernon, WA, and Bonners Ferry and Aberdeen, ID in 2001 to 2003. Efficacy was assessed by artificially inoculating harvested tubers. Mean incidence and severity of late blight tuber rot in tubers inoculated with US-8 and US-11 isolates of Phytophthora infestans usually were significantly less when the foliage from which the tubers were obtained was treated with phosphorous acid than when it was not treated at all locations. With two applications of phosphorous acid, late blight tuber rot in the tuber-resistant cv. Umatilla Russet was significantly less than for Ranger Russet. For phosphorous acid at a rate of $9.37 \mathrm{~kg}$ a.i./ha, late blight tuber rot control achieved with two applications at 2-week intervals was not consistently improved across locations by making an additional application 2 weeks later. In 2003, incidence and severity of late blight tuber rot did not differ significantly between the rates of 7.49 and $9.37 \mathrm{~kg}$ a.i./ha at both Othello and Mount Vernon. Late blight tuber rot incidence and severity were significantly less at a rate of $7.49 \mathrm{~kg}$ a.i./ha when the application schedule began at initial tuber bulking rather than when the first application was made 4 weeks after initial tuber bulking at Othello, but not Mount Vernon. Incidence of pink rot was significantly less in inoculated tubers from plots treated with three applications of phosphorous acid than in tubers from nontreated control plots at Mount Vernon in 2002 and 2003, Bonners Ferry in 2002, and Aberdeen in 2003. Pink rot severity was reduced significantly by both two and three phosphorous acid applications at Mount Vernon in 2002. Pink rot incidence, but not severity, was reduced significantly at all timings when either 7.49 or $9.37 \mathrm{~kg}$ a.i./ha was applied at Mount Vernon in 2003. Control of Pythium spp. by phosphorous acid was not evident in this study. Total tuber yield at harvest did not differ significantly among the phosphorous acid treatments and the nontreated control at Othello and Mount Vernon in 2001 and 2002.
\end{abstract}

Additional keywords: Pythium leak

Potato tubers can be infected by several oomycetes. These include Phytophthora infestans, cause of late blight, $P$. erythroseptica and Phytophthora spp., cause of pink rot, and Pythium ultimum and Pythium spp., cause of Pythium leak $(9,27,29)$. Tuber rots caused by Phytophthora infestans can be severe in the U.S. Pacific Northwest (Washington, Ore-

Corresponding author: D. A. Johnson

E-mail: dajohn@wsu.edu

Supporting funds were provided by the Washington State Potato Commission, Idaho Potato Commission, and Nufarm Americas Inc.

Plant Pathology Number Series 0373, Department of Plant Pathology, College of Agriculture and Home Economics Research Center, Project 0678, Washington State University, Pullman.

Accepted for publication 11 June 2004.

Publication no. D-2004-0809-02R

(C) 2004 The American Phytopathological Society gon, and Idaho), where a substantial portion of the potato crop is dedicated to processing and, consequently, long-term storage. Tuber losses in storage in the Columbia Basin due to rot caused by $P$. infestans were estimated at \$3 and \$1.4 million in 1995 and 1998, respectively $(16,17)$. Pink rot and Pythium leak also are present most years in the Pacific Northwest. Recently, incidence of pink rot has increased and is regarded as an emerging disease problem in the Pacific Northwest. Severe damage due to leak also has been observed at selected locations (14).

Although host resistance can be an effective means of managing plant diseases, foliage and tubers of nearly all widely grown commercial potato cultivars in the Pacific Northwest are susceptible to $P$. infestans $(15,25,26)$. Tubers of Umatilla Russet are resistant, but foliage is susceptible to late blight. Tubers of most potato cultivars currently grown in the United States are susceptible to pink rot and leak (27). Consequently, fungicide use has been a primary management practice for these three diseases.

Metalaxyl and mefenoxam have been effective in the past in controlling potato tuber rots caused by Phytophthora and Pythium spp. (22,30,31), but mefenoxamresistant populations of $P$. infestans now predominate in the Pacific Northwest (7,20,21). Mefenoxam-resistant isolates of P. erythroseptica and Pythium ultimum are becoming more widely prevalent in North America, including the Pacific Northwest $(14,29)$. Control by metalaxyl and mefenoxam products is no longer effective against these pathogens in some fields, and alternative control measures are needed.

Phosphorous acid (phosphonate or phosphite) is the anionic metabolite of the systemic fungicide aluminum tris-O-ethyl phosphonate (fosetyl-Al) (23). Both phosphorous acid and fosetyl-Al are effective in controlling diseases caused by oomycetes $(2,3,11,23)$. The mode of action is direct antifungal activity of phosphonate toward mycelial growth (10) and, perhaps, indirect stimulation of host defenses $(8,12,13)$. These compounds are systemic in both a basipetal and acropetal direction (4), and this systemic property permits their use as a foliar spray for control of root rots caused by Phytophthora spp. (3) and other oomycetes. Even though phosphonates are reduced phosphorus compounds, they do not effectively replace phosphates as a source of phosphorus plant nutrition in tomato and pepper (11).

Phosphorous acid formulations did not sufficiently reduce foliar infections caused by Phytophthora infestans to be considered an effective control for late blight on potato foliage in the field (6). However, phosphonate appears to be stable in plants for several weeks $(24,28)$, and may offer long-term protection in potato tubers. Phosphorous acid (phosphonic acid) applied to potato foliage reduced incidence of inoculated tubers that became infected with $P$. infestans in Ireland $(5,6)$. The potential influences of potato cultivar, geographic location, application rate, and timing of applications of phosphorous acid on control of late blight warrant further investigation $(5,6)$.

The purpose of this study was to evaluate applications of phosphorous acid on foliage of commercial potato cultivars at various application timings and rates for the control of potato tuber infections 
caused by $P$. infestans, $P$. erythroseptica, and Pythium ultimum in the Pacific Northwest. Cultivars with various levels of tuber resistance to Phytophthora infestans and $P$. erythroseptica were used to assess the combined effects of the systemic fungicide plus host resistance on tuber rot incidence and severity.

\section{MATERIALS AND METHODS}

Trials were conducted at three locations on a silt loam near Othello, WA in 2001 to 2003, on a silt loam near Mount Vernon, WA in 2002 and 2003, on a sandy silt loam near Bonners Ferry, ID in 2002, and on a silt loam near Aberdeen, ID in 2003. Othello is in a semiarid environment of the Columbia Basin where potato plants are irrigated mostly with center pivot irrigation. Mount Vernon is in the maritime environment of northwestern Washington where rainfall during the growing season averages $83 \mathrm{~cm}$ and commercial potato crops are irrigated only during dry periods. Bonners Ferry is on the western slopes of the Rocky Mountains where the average rainfall is $14 \mathrm{~cm}$ during the growing season. Aberdeen, ID is in a semiarid environment of the Snake River Plain where rainfall during the growing season averages 10 $\mathrm{cm}$ and potato crops are irrigated by center pivot and set-and-move irrigation pipe.

One or two potato cultivars were grown at each location. Tubers of Ranger Russet, Russet Norkotah, Russet Burbank, and White Rose are susceptible to P. infestans, $P$. erythroseptica, and Pythium ultimum; tubers of Umatilla Russet are moderately resistant to Phytophthora infestans, but susceptible to $P$. erythroseptica and $P y$ thium ultimum $(15,19,25,26)$. Tubers of Russet Norkotah are more susceptible to Phytophthora erythroseptica than those of Russet Burbank. Ranger Russet and Russet Burbank are among the russet-skinned cultivars that appear to have lower susceptibility to eye infection by $P$. erythroseptica (27).
Certified potato seed was planted at 23to $25-\mathrm{cm}$ spacing within rows and at between-row spacing of $86 \mathrm{~cm}$ at Othello and Bonners Ferry, $97 \mathrm{~cm}$ at Mount Vernon, and $91 \mathrm{~cm}$ at Aberdeen. Plot size was three rows $(2.6 \mathrm{~m})$ wide and $4.6 \mathrm{~m}$ long at Othello, four rows $(3.7 \mathrm{~m})$ wide and $6.1 \mathrm{~m}$ long at Bonners Ferry and Aberdeen, onerow $(1 \mathrm{~m})$ wide and $4.6 \mathrm{~m}$ long at Mount Vernon in 2002, and three rows $(3.2 \mathrm{~m})$ wide and $3.0 \mathrm{~m}$ long at Mount Vernon in 2003. Planting dates are listed in Table 1. Plots were fertilized and weeds were managed with herbicides according to standard practices at each of the three locations. Foliage was treated at 7- to 14-day intervals after row closure with cymoxanil (Curzate $60 \mathrm{DF}$ at $224 \mathrm{~g}$ a.i./ha), mancozeb (Dithane DF Rainshield at $1.68 \mathrm{~kg}$ a.i./ha), or chlorothalonil (Bravo WS at $1.26 \mathrm{~kg}$ a.i./ha) using a tractor-driven sprayer to control late blight on foliage.

Phosphorous acid (Phostrol, mono- and dibasic sodium, potassium, and ammonium phosphates 53.6\%; other ingredients 46.4\%; Nufarm Americas Inc., Houston, TX) was applied in 2001 to foliage of Ranger Russet at Othello; in 2002 to Ranger Russet and Umatilla Russet at Othello, to Umatilla Russet and White Rose at Mount Vernon, and to Russet Burbank and Russet Norkotah at Bonners Ferry; and in 2003 to Ranger Russet at Othello, to Russet Burbank at Mount Vernon, and to Russet Norkotah at Aberdeen. Applications of phosphorous acid were made in water at 327 to 374 liters/ha (35 to $40 \mathrm{gpa}$ ) and $207 \mathrm{kPa}$ (30 psi) via carbon dioxide backpack sprayers with ConeJet TXVS-18 nozzles at Othello, Flat fan 8002 TeeJet nozzles at Mount Vernon, Flat fan 8004 TeeJet nozzles at Bonners Ferry, and Flat fan XR11001 VS TeeJet nozzles at Aberdeen. There was some variation in treatment rates and timings among years and locations. In 2001, phosphorous acid at $9.37 \mathrm{~kg}$ a.i./ha (11.69 liters/ha, $10 \mathrm{pt} / \mathrm{a})$ was applied twice, and phosphorous acid at $4.68 \mathrm{~kg}$ a.i./ha (5.85 liters/ha, $5 \mathrm{pt} / \mathrm{a})$ and $9.37 \mathrm{~kg}$ a.i./ha each were applied three times at Othello. In 2002, phosphorous acid at $9.37 \mathrm{~kg}$ a.i./ha was applied twice and three times at each of the three locations. In 2003, phosphorous acid at $9.37 \mathrm{~kg}$ a.i./ha was applied three times at Aberdeen. Initial applications were 1 week after initial tuber bulking (i.e., tubers approximately 14 to $70 \mathrm{~g}$ in weight), which was 70 days after planting (DAP) in 2001 and 2002 at Othello, 55 DAP in 2002 at Mount Vernon, 66 DAP in 2002 at Bonners Ferry, and 51 DAP in 2003 at Aberdeen (Table 1).

In 2003, phosphorous acid at $7.49 \mathrm{~kg}$ a.i./ha (9.35 liters/ha, $8 \mathrm{pt} / \mathrm{ha})$ and $9.37 \mathrm{~kg}$ a.i./ha was applied on three successive application schedules consisting of three applications each at both Othello and Mount Vernon. The timing of the first application for the three sequence schedules were 76, 90, and 105 DAP at Othello, and 54, 68, and 82 DAP at Mount Vernon (Table 1). The interval between applications for each sequence was approximately 2 weeks at both locations. The first application of the earliest sequence was 1 week after initial tuber bulking. Specific treatments were (i) first application at initial tuber bulking with two more applications at 2-week intervals, (ii) first application 2 weeks after initial tuber bulking with two more applications at 2-week intervals, (iii) first application 4 weeks after initial tuber bulking with two more applications at 2week intervals, and (iv) nontreated control. Tubers from plots not treated with phosphorous acid were used as the nontreated control for each location for all trials. Each year at all locations, phosphorous acid treatments were arranged in a randomized complete block design with four replicates.

Foliage at Mount Vernon and Bonners Ferry was vine killed before harvest with herbicide (Table 1). Plots were harvested on 16 to 20 September 2001-03 at Othello, on 24 September 2002 and 22 September

Table 1. Summary of planting dates, phosphorous acid application dates, and harvest dates for research plots used to investigate control of potato tuber rots at Othello, WA, Mount Vernon, WA, and Bonners Ferry, ID ${ }^{\mathrm{z}}$

\begin{tabular}{|c|c|c|c|c|c|c|c|c|c|}
\hline \multirow[b]{2}{*}{ Year/location } & \multirow[b]{2}{*}{ Planting } & \multicolumn{2}{|c|}{ First application } & \multicolumn{2}{|c|}{ Second application } & \multicolumn{2}{|c|}{ Third application } & \multirow[b]{2}{*}{ Kill } & \multirow[b]{2}{*}{ Harvest } \\
\hline & & Date & DAP & Date & DAP & Date & DAP & & \\
\hline \multicolumn{10}{|l|}{2001} \\
\hline Othello & $4 / 19$ & $6 / 28$ & 70 & $7 / 14$ & 86 & $7 / 25$ & 97 & $\ldots$ & $9 / 20$ \\
\hline \multicolumn{10}{|l|}{2002} \\
\hline Othello & $4 / 18$ & $6 / 27$ & 70 & $7 / 11$ & 84 & $7 / 25$ & 98 & & $9 / 16$ \\
\hline Mount Vernon & $5 / 24$ & $7 / 18$ & 55 & $8 / 1$ & 69 & $8 / 15$ & 83 & $8 / 30$ & $9 / 24$ \\
\hline Bonners Ferry & $5 / 25$ & $7 / 30$ & 66 & $8 / 13$ & 80 & $8 / 27$ & 94 & $9 / 20$ & $10 / 9$ \\
\hline \multicolumn{10}{|l|}{2003} \\
\hline \multicolumn{10}{|l|}{ Othello } \\
\hline Schedule 1 & $4 / 23$ & $7 / 8$ & 76 & $7 / 22$ & 90 & $8 / 6$ & 105 & $\ldots$ & $9 / 16$ \\
\hline Schedule 2 & $4 / 23$ & $7 / 22$ & 90 & $8 / 6$ & 105 & $8 / 18$ & 117 & $\ldots$ & $9 / 16$ \\
\hline Schedule 3 & $4 / 23$ & $8 / 6$ & 105 & $8 / 18$ & 117 & $9 / 4$ & 134 & $\ldots$ & $9 / 16$ \\
\hline \multicolumn{10}{|l|}{ Mount Vernon } \\
\hline Schedule 1 & $5 / 8$ & $7 / 1$ & 54 & $7 / 15$ & 68 & $7 / 29$ & 82 & $9 / 2$ & $9 / 22$ \\
\hline Schedule 2 & $5 / 8$ & $7 / 15$ & 68 & $7 / 29$ & 82 & $8 / 12$ & 96 & $9 / 2$ & $9 / 22$ \\
\hline Schedule 3 & $5 / 8$ & $7 / 29$ & 82 & $8 / 12$ & 96 & $8 / 26$ & 110 & $9 / 2$ & $9 / 22$ \\
\hline Aberdeen & $5 / 6$ & $7 / 2$ & 51 & $7 / 16$ & 71 & $7 / 30$ & 85 & $8 / 22$ & $9 / 12$ \\
\hline
\end{tabular}

${ }^{\mathrm{z}}$ Date $=$ month/day, DAP $=$ days after planting. 
2003 at Mount Vernon, on 10 October 2002 at Bonners Ferry, and on 22 August 2003 at Aberdeen (Table 1). Tuber yields were determined in 2001 and 2002 at both Othello and Mount Vernon and in 2003 at Aberdeen. A single-row potato harvester was used at all locations except at Bonners Ferry, where tubers were lifted from the soil and dropped back to the ground with a modified commercial harvester.

Harvested tubers were inoculated with US-8 (A2 mating type) or US-11 (A1 mating type) clonal lineages of $P$. infestans. In 2001, Othello tubers were inoculated at the Pullman laboratory with US-8 (metalaxylresistant isolate $\mathrm{CB} 01$ obtained from potato in the Columbia Basin) 1 day after harvest (DAH). In 2002, Othello tubers were inoculated with US-8 (metalaxylresistant isolate $\mathrm{CB} 02$ obtained from potato in the Columbia Basin) at the Pullman laboratory $2 \mathrm{DAH}$, and US-11 (metalaxylresistant isolate $110 \mathrm{~B}$ obtained from hairy nightshade in western Washington) at the Mount Vernon laboratory 7 DAH. Also in 2002, Mount Vernon tubers were inoculated with US-8 isolate WA02 at the Pullman laboratory $5 \mathrm{DAH}$, and US-11 at the Mount Vernon laboratory 8 DAH. Bonners Ferry tubers were inoculated with US- 8 isolate CB02 at the Pullman laboratory 4 DAH. In 2003, Othello tubers were inoculated with US-8 isolate CB02 at the Pullman laboratory $1 \mathrm{DAH}$, and Mount Vernon tubers were inoculated with US-11 at the Mount Vernon laboratory 21 DAH. Number of tubers inoculated from each plot for each isolate was 10 in 2001 and 2002, 6 at Othello in 2003, and 5 at Mount Vernon in 2003.

All three isolates of $P$. infestans were maintained on rye agar medium at $18^{\circ} \mathrm{C}$ or in inoculated tubers of Russet Burbank that were stored at $5^{\circ} \mathrm{C}$. US- 8 and US-11 inoculum was increased on leaflets of cvs. Russet Burbank and White Rose, respectively, on moistened paper towels in sealed plastic containers at $15^{\circ} \mathrm{C}$. Sporangia were washed from sporulating lesions on the leaflets, the resultant sporangial suspension was adjusted to 10,000 sporangia/ml using a hemacytometer, and the suspension was chilled at $4^{\circ} \mathrm{C}$ for $2 \mathrm{~h}$ before inoculation.

Tubers were inoculated at the Pullman laboratory with US- 8 by placing $0.05 \mathrm{ml}$ of the sporangial suspension on a $1-\mathrm{cm}$ filter paper square, and transferring the square to a bud near the center of the tuber. Tubers were placed in a mist chamber for $18 \mathrm{~h}$ at 18 to $20^{\circ} \mathrm{C}$, air dried for $24 \mathrm{~h}$ at $20^{\circ} \mathrm{C}$, and then incubated for 31 days at $8^{\circ} \mathrm{C}$.

Tubers were inoculated with US-11 at the Mount Vernon laboratory in 2002 by selecting a site near an eye, cutting a section of the periderm $1 \mathrm{~cm}^{2}$ by $5 \mathrm{~mm}$ deep with a scalpel, inserting a $5-\mathrm{mm}^{2}$ plug of colonized rye agar medium, and atomizing the tubers with water before and periodically during incubation in nylon netted bags for 17 days at $13^{\circ} \mathrm{C}$. To avoid wounding in 2003 , tubers were inoculated by first atomizing a 10,000-sporangia/ml suspension at $0.5 \mathrm{ml} /$ tuber, then placing a $1-\mathrm{cm}$ diameter filter paper disc briefly dipped in the suspension onto the apical end. Inoculated tubers were incubated in plastic bags on top of moist paper toweling for 49 days at approximately $5^{\circ} \mathrm{C}$.

At the Mount Vernon laboratory, Mount Vernon tubers were inoculated with $P$. erythroseptica (metalaxyl-sensitive isolate $6 \mathrm{E}$ obtained from potato in Maine by D. Lambert) in 2002, and Pythium ultimum (metalaxyl-resistant isolate I2 obtained in Oregon by P. Hamm) in 2002 and 2003 using the same method as for US-11 Phytophthora infestans in 2002. To vary inoculation method, tubers were inoculated with $P$. erythroseptica (metalaxyl-resistant isolate, ID03, obtained from potato in Idaho by L. Porter) in 2003 by pipetting a $50-\mu \mathrm{l}$ suspension of $10,000 \mathrm{zoospore} / \mathrm{ml}$ onto the stem end and placing a $1-\mathrm{cm}$-diameter filter paper disc dipped to saturation in the suspension onto the apical end near an eye of each tuber. In 2002, tubers inoculated with $P$. erythroseptica were incubated for 17 days at $13^{\circ} \mathrm{C}$ and tubers inoculated with Pythium ultimum were incubated for 23 days at $13^{\circ} \mathrm{C}$. In 2003, tubers inoculated with Phytophthora erythroseptica were incubated for 39 days at $5^{\circ} \mathrm{C}$ and tubers inoculated with Pythium ultimum were incubated for 9 days at $15^{\circ} \mathrm{C}$.

At the Aberdeen laboratory in 2002, Bonners Ferry tubers were inoculated by dipping the bud end of each tuber in a zoospore suspension of $P$. erythroseptica (isolate PR02-21, metalaxyl-sensitive) at 20,000 zoospores/ml for approximately 1 s. Inoculum was chilled at $4^{\circ} \mathrm{C}$ for $1.5 \mathrm{~h}$ and then warmed for $0.5 \mathrm{~h}$ at $20^{\circ} \mathrm{C}$ before inoculation. Tubers were wrapped in paper towels saturated with distilled water after inoculation, then incubated for 14 days at $15^{\circ} \mathrm{C}$. In 2003 , Aberdeen tubers were inoculated using a technique similar to that utilized at Mount Vernon in 2003. A 1-cmdiameter filter paper disc was dipped to saturation in a zoospore suspension (20,000 zoospore/ml), then placed onto the apical end of each tuber near an eye. Tests comparing tuber dip and disc inoculation methods showed that both techniques gave similar levels of tuber infection. Using filter paper discs was easier, however, because less inoculum was required. For this reason, the inoculation technique changed from 2002 to 2003.

After incubation, all inoculated tubers were cut in half longitudinally and severity was assessed visibly for each one as the percent area with late blight, pink rot, or leak symptoms. If late blight symptoms were not observed, additional cuts were made near the inoculation site to insure that the tuber was not infected. Average severity was calculated for all symptomatic and asymptomatic tubers to obtain a measure of the total amount of rot in bulk storage for each treatment. At Pullman, tuber slices with late blight symptoms were placed on moistened filter paper in petri dishes for $18 \mathrm{~h}$ at $18^{\circ} \mathrm{C}$ to induce sporulation. In this study, disease severity was a measure of volume of infected tissue of all tubers exposed to a pathogen while disease incidence was the percentage of tubers infected.

Data for disease incidence, disease severity, and yield were analyzed by analysis of variance using the PROC GLM procedure of SAS (SAS institute, Inc., Cary, NC). Mean separation was performed using the Fisher's protected least significant difference test when the $F$ test was significant $(P<0.05)$ for a test factor. Significant $(P<0.05)$ cultivar-phosphorous acid treatment interactions for incidence of late blight were detected at Othello in 2002 and Bonners Ferry in 2002 and cultivars were considered separately in the analysis for those two locations. Single degree of freedom contrasts were used to evaluate differences in late blight tuber rot between cultivars treated with phosphorous acid at Othello and Bonners Ferry in 2002. A cultivar-treatment interaction was not detected for incidence or severity of late blight at Mount Vernon in 2002 and cultivars at that location were combined in the analysis $(P>0.05)$. Significant cultivarphosphorous acid treatment interactions for pink rot incidence and severity were not detected at any location in 2002 and $2003(P>0.05)$ and cultivars were combined for analysis of pink rot data.

\section{RESULTS}

Mean incidence and severity of late blight tuber rot in tubers inoculated with an US-8 isolate of $P$. infestans were usually less $(P<0.05)$ when foliage was treated with phosphorous acid than when it was not treated for cultivars grown at Othello in 2001-03, Mount Vernon in 2002 and 2003, and Bonners Ferry in 2002 (Tables 2, 3, and 4). Incidence of late blight tuber rot in tubers inoculated with an US11 isolate of $P$. infestans was less $(P<$ $0.05)$ when foliage was treated with three applications of phosphorous acid than when foliage was not treated at Mount Vernon in 2002 (Table 2), and for Russet Burbank grown at Mount Vernon in 2003 (Table 3). Severity of tuber rot in tubers inoculated with the US-11 isolate was less $(P<0.05)$ when foliage was treated with phosphorous acid than when foliage was not treated for Ranger Russet grown at Othello in 2002 (Table 2) and for Russet Burbank grown at Mount Vernon in 2003 (Table 3).

In 2001 at Othello, mean incidence and severity of late blight tuber rot for Ranger Russet inoculated with a US-8 isolate of $P$. infestans were less $(P<0.05)$ with three applications of phosphorous acid at 9.37 
$\mathrm{kg}$ a.i./ha than with two applications at $9.37 \mathrm{~kg}$ a.i./ha, and incidence and severity blight tubers was less $(P<0.05)$ with two applications of phosphorous acid at $9.37 \mathrm{~kg}$ a.i./ha than with three applications at 4.68 $\mathrm{kg}$ a.i./ha. Mean severity but not mean incidence of blighted tubers was less $(P<0.05)$ in tubers from foliage treated with three applications at $4.68 \mathrm{~kg}$ a.i./ha compared with the nontreated control (Table 2).

In 2002 at Othello and Bonners Ferry, mean incidence of late blight tuber rot for Ranger Russet and Russet Norkotah tubers, respectively, inoculated with the US8 isolate of $P$. infestans was less with three applications than with two applications of

Table 2. Mean incidence and severity of late blight on tubers inoculated with Phytophthora infestans after foliage was treated with phosphorous acid in the field at Othello, WA in 2001 and Othello and Mount Vernon, WA and Bonners Ferry, ID in 2002

\begin{tabular}{|c|c|c|c|c|}
\hline \multirow[b]{2}{*}{ Year, location, cultivar, treatment ${ }^{v}$} & \multicolumn{2}{|c|}{ Incidence } & \multicolumn{2}{|c|}{ Severity } \\
\hline & $\mathbf{U S - 8}^{\mathbf{w}}$ & US-11 $^{x}$ & $\mathbf{U S - 8}^{\mathbf{w}}$ & US-11 ${ }^{x}$ \\
\hline \multicolumn{5}{|l|}{2001 Othello } \\
\hline \multicolumn{5}{|l|}{ Ranger Russet ${ }^{\mathrm{y}}$} \\
\hline Nontreated control & $100 \mathrm{c}$ & $\ldots$ & $72 \mathrm{~d}$ & $\ldots$ \\
\hline Three applications at $4.68 \mathrm{~kg}$ a.i./ha & $95 \mathrm{c}$ & $\ldots$ & $36 \mathrm{c}$ & $\ldots$ \\
\hline Two applications at $9.37 \mathrm{~kg}$ a.i./ha & $68 \mathrm{~b}$ & $\ldots$ & $17 \mathrm{~b}$ & $\ldots$ \\
\hline Three applications at $9.37 \mathrm{~kg}$ a.i./ha & $21 \mathrm{a}$ & $\ldots$ & $6 \mathrm{a}$ & $\ldots$ \\
\hline \multicolumn{5}{|l|}{2002 Othello } \\
\hline \multicolumn{5}{|l|}{ Ranger Russet ${ }^{\mathrm{y}}$} \\
\hline Nontreated control & $90 \mathrm{c}$ & 100 & $70 \mathrm{~b}$ & $46 \mathrm{~b}$ \\
\hline Two applications at $9.37 \mathrm{~kg}$ a.i./ha & $53 \mathrm{~b}$ & 100 & $20 \mathrm{a}$ & $35 \mathrm{a}$ \\
\hline Three applications at $9.37 \mathrm{~kg}$ a.i./ha & $15 \mathrm{a}$ & 98 & $4 \mathrm{a}$ & $29 \mathrm{a}$ \\
\hline \multicolumn{5}{|l|}{ Umatilla Russet } \\
\hline Nontreated control & $28 \mathrm{~b}$ & 95 & $5 \mathrm{~b}$ & 19 \\
\hline Two applications at $9.37 \mathrm{~kg}$ a.i./ha & $15 \mathrm{ab}$ & 75 & $1 \mathrm{a}$ & 16 \\
\hline Three applications at $9.37 \mathrm{~kg}$ a.i./ha & $0 \mathrm{a}$ & 70 & $0 \mathrm{a}$ & 14 \\
\hline \multicolumn{5}{|c|}{2002 Mount Vernon } \\
\hline \multicolumn{5}{|c|}{ White Rose and Umatilla Russet combined ${ }^{\mathrm{z}}$} \\
\hline Nontreated control & $51 \mathrm{~b}$ & $94 \mathrm{~b}$ & $10 \mathrm{~b}$ & 27 \\
\hline Two applications at $9.37 \mathrm{~kg}$ a.i./ha & $20 \mathrm{a}$ & $74 \mathrm{ab}$ & $3 \mathrm{a}$ & 13 \\
\hline Three applications at $9.37 \mathrm{~kg}$ a.i./ha & $19 \mathrm{a}$ & $65 \mathrm{a}$ & $2 \mathrm{a}$ & 11 \\
\hline \multicolumn{5}{|l|}{2002 Bonners Ferry } \\
\hline \multicolumn{5}{|l|}{ Russet Norkotah ${ }^{\mathrm{y}}$} \\
\hline Nontreated control & $98 \mathrm{c}$ & $\ldots$ & $25 \mathrm{~b}$ & $\ldots$ \\
\hline Two applications at $9.37 \mathrm{~kg}$ a.i./ha & $10 \mathrm{~b}$ & $\ldots$ & $1 \mathrm{a}$ & $\ldots$ \\
\hline Three applications at $9.37 \mathrm{~kg}$ a.i./ha & $0 \mathrm{a}$ & $\ldots$ & $0 \mathrm{a}$ & $\ldots$ \\
\hline \multicolumn{5}{|l|}{ Russet Burbank ${ }^{\mathrm{y}}$} \\
\hline Nontreated control & $65 \mathrm{~b}$ & $\ldots$ & $11 \mathrm{~b}$ & $\ldots$ \\
\hline Two applications at $9.37 \mathrm{~kg}$ a.i./ha & $0 \mathrm{a}$ & $\ldots$ & $0 \mathrm{a}$ & $\ldots$ \\
\hline Three applications at $9.37 \mathrm{~kg}$ a.i./ha & $3 \mathrm{a}$ & $\ldots$ & $2 \mathrm{a}$ & $\ldots$ \\
\hline
\end{tabular}

u Means of four replicates and 10 tubers (subsamples)/replicate. Values within the same column and year and location category followed by the same letter are not significantly different at $P=0.05$, according to Fisher's protected least significant difference test; $\ldots=$ not included in test.

$\checkmark$ Application dates are listed in Table 1.

${ }^{w}$ US-8 clonal lineage of $P$. infestans.

${ }^{x}$ US-11 clonal lineage of $P$. infestans.

${ }^{y}$ Cultivars are listed separately due to significant $(P=0.05)$ cultivar-treatment interaction.

${ }^{\mathrm{z}}$ Cultivars are combined because of no significant $(P>0.05)$ cultivar-treatment interaction.

phosphorous acid at $9.37 \mathrm{~kg}$ a.i./ha, but mean severity did not differ $(P>0.05)$ between two and three applications at 9.37 $\mathrm{kg}$ a.i./ha (Table 2). Mean incidence and severity of late blight tuber rot for Umatilla Russet at Othello and Russet Burbank at Bonners Ferry inoculated with the US-8 isolate of $P$. infestans did not differ $(P>$ $0.05)$ between three and two applications at $9.37 \mathrm{~kg}$ a.i./ha in 2002 . Incidence and severity of late blight tuber rot for White Rose and Umatilla Russet at Mount Vernon did not differ $(P>0.05)$ between the twoand three-application rates when tubers were inoculated with either the US-8 and US-11 isolates (Table 2). With two applications of phosphorous acid, late blight tuber rot in the tuber-resistant cv. Umatilla Russet was less $(P<0.05)$ than it was for Ranger Russet when values were tested with single-degree of freedom contrasts at Othello in 2002 (contrast not shown). Incidence and severity of late blight tuber rot did not differ $(P>0.05)$ between Russet Norkotah and Russet Burbank when treated with phosphorous acid at Bonners Ferry in 2002.

In 2003, severity and incidence of late blight tuber rot were less $(P<0.05)$ than the nontreated control with phosphorous acid at 7.49 and $9.37 \mathrm{~kg}$ a.i./ha for each of the application schedules at Mount Vernon (Table 3) and Othello (Table 4). Incidence and severity of late blight tuber rot did not differ $(P>0.05)$ between the 7.49 and 9.37 $\mathrm{kg}$ a.i./ha rates at either location. Tuber rot incidence and severity at Othello were less $(P<0.05)$ at the $7.49 \mathrm{~kg}$ a.i./ha rate when the application schedule began at initial tuber bulking compared with when the application schedule began 4 weeks after initial tuber bulking (Table 4).

Incidence of pink rot was less $(P<0.05)$ in inoculated tubers from plots treated with three applications of phosphorous acid than from nontreated control plots at Mount Vernon in 2002 and 2003, at Bonners Ferry in 2002, and at Aberdeen in 2003 (Tables 3 and 5). Severity of pink rot

Table 3. Mean incidence and severity of rot on tubers inoculated with a Phytophthora infestans isolate of the US-11 clonal linage, Phytophthora erythroseptica or Pythium ultimum after foliage of Russet Burbank was treated with three applications of phosphorous acid on three successive application schedules at Mount Vernon in $2003^{\mathrm{w}}$

\begin{tabular}{|c|c|c|c|c|c|c|}
\hline \multirow[b]{2}{*}{ Treatment, application timing } & \multicolumn{3}{|c|}{ Incidence $(\%)$} & \multicolumn{3}{|c|}{ Severity (\%) } \\
\hline & Late blight & Pink rot & Pythium leak & Late blight & Pink rot & Pythium leak \\
\hline Control & $80 \mathrm{~b}$ & $60 \mathrm{~b}$ & 100 & $48 \mathrm{~b}$ & $56 \mathrm{c}$ & 75 \\
\hline \multicolumn{7}{|l|}{ Phosphorous acid, $7.49 \mathrm{~kg}$ a.i./ha } \\
\hline Initial bulking +2 weeks +2 weeks $^{x}$ & $30 \mathrm{a}$ & $25 \mathrm{a}$ & 100 & $8 \mathrm{a}$ & $12 a b c$ & 71 \\
\hline 2 weeks after initial bulking +2 weeks +2 weeks $y$ & $30 \mathrm{a}$ & $20 \mathrm{a}$ & 100 & $15 \mathrm{a}$ & $16 \mathrm{bc}$ & 76 \\
\hline 4 weeks after initial bulking +2 weeks +2 weeks $^{\mathrm{z}}$ & $30 \mathrm{a}$ & $15 \mathrm{a}$ & 100 & $12 \mathrm{a}$ & $6 \mathrm{ab}$ & 77 \\
\hline \multicolumn{7}{|l|}{ Phosphorous acid, $9.37 \mathrm{~kg}$ a.i./ha } \\
\hline Initial bulking +2 weeks +2 weeks $^{x}$ & $10 \mathrm{a}$ & $0 \mathrm{a}$ & 100 & $1 \mathrm{a}$ & $0 \mathrm{a}$ & 63 \\
\hline 2 weeks after initial bulking +2 weeks +2 weeks $y$ & $10 \mathrm{a}$ & $5 \mathrm{a}$ & 100 & $3 \mathrm{a}$ & $4 a b$ & 67 \\
\hline 4 weeks after initial bulking +2 weeks +2 weeks ${ }^{z}$ & $15 \mathrm{a}$ & $15 \mathrm{a}$ & 100 & $2 \mathrm{a}$ & $15 \mathrm{ab}$ & 81 \\
\hline
\end{tabular}

${ }^{\text {w}}$ Mean of four replicates and five tubers per replicate. Means within the same column followed by the same letter are not significantly different at $P=0.05$, according to Fisher's protected least significant difference test.

${ }^{\mathrm{x}}$ Initial application on 1 July.

y Initial application on 15 July.

${ }^{\mathrm{z}}$ Initial application on 29 July. 
was less $(P<0.05)$ from plots treated with phosphorous acid than from nontreated control plots at Othello and Mount Vernon in 2002 (Table 5). Incidence and severity of pink rot was less for tubers from foliage treated with three applications than two applications at $9.37 \mathrm{~kg}$ a.i./ha at Mount Vernon in 2002 (Table 5), but severity of pink rot at Othello and incidence of pink rot at Bonners Ferry did not differ $(P>$ $0.5)$ between two and three applications at the $9.37 \mathrm{~kg}$ a.i./ha rate (Table 5). Pink rot incidence in 2003 was reduced at all timings for both 7.49 and $9.37 \mathrm{~kg}$ a.i./ha at Mount Vernon (Table 3). Pink rot severity was significantly reduced at the application rate of $7.49 \mathrm{~kg}$ a.i. only when initially applied 4 weeks after initiation of bulking.

Incidence and severity of Pythium leak did not differ $(P>0.05)$ for inoculated tubers from foliage treated with phosphorous acid and the nontreated control (Tables 3 and 5).

Total tuber yield at harvest did not differ significantly $(P>0.05)$ among the phosphorous acid treatments and the nontreated control at Othello in 2001 and 2002 or Mount Vernon in 2002 and 2003. However, total yield from the phosphorous acid treatment ( $49 \mathrm{t} / \mathrm{ha}$ ) was significantly higher than the nontreated control (42 t/ha) at Aberdeen in 2003 (data not shown). Yield data were not taken at Bonners Ferry in 2002.

\section{DISCUSSION}

Late blight was reduced in tubers inoculated after harvest when foliage of four late blight-susceptible cultivars and one moderately tuber-resistant potato cultivar, all commonly grown in the Pacific Northwest, was treated with phosphorous acid at 7.49 and $9.37 \mathrm{~kg}$ a.i./ha. Three applications were not consistently better than two applications at the $9.37 \mathrm{~kg}$ a.i./ha rate when evaluated at three widely separated and diverse locations. Applications beginning when tuber bulking was beginning were more effective than applications made 4 weeks after initial tuber bulking at one of two locations. Potato cultivar had an effect on the amount of phosphorous acid needed to manage late blight tuber rot. Incidence of blighted tubers at Othello of a tuberresistant cultivar, Umatilla Russet, was equivalent or less with two applications of phosphorous acid compared with three applications at the same rate on the susceptible cv. Ranger Russet.

In Ireland, incidence of late blight tuber rot after artificial inoculation was most effectively reduced using five to six applications of phosphorous acid (phosphonic acid) at $2 \mathrm{~kg} / \mathrm{ha}$ at 10 - to 14-day intervals, although a single application of $4 \mathrm{~kg} / \mathrm{ha}$ applied mid- or late-season also proved effective in reducing tuber rot (5). In our study, severity of late blight tuber rot was reduced significantly with three applications of $4.68 \mathrm{~kg}$ a.i./ha; however, incidence of infected tubers was not reduced. The difference in effectiveness of phosphorous acid rates between Ireland and the U.S. Pacific Northwest may be due to cultivars, environments, and product formulations.

Both disease incidence and severity were used to assess levels of tuber rot in this study, and both are beneficial measures when evaluating control practices for late blight tuber rot. Disease severity is a measure of volume of rotten tissue of all inoculated tubers and reflects restricted lesion or rot expansion in infected tubers from foliage treated with phosphorous acid. It also indicates the total amount of rot in bulk storage and would be a valuable statistic in managing stored tubers over various time periods. Tubers with low severity of blight may be marketable if processed quickly. Disease incidence is a

Table 4. Mean incidence and severity of late blight on tubers inoculated with a Phytophthora infestans isolate of the US-8 clonal linage after foliage of Ranger Russet was treated with three applications of phosphorous acid on three successive application schedules at Othello in $2003^{\mathrm{w}}$

\begin{tabular}{|c|c|c|}
\hline Treatment & Incidence (\%) & Severity $(\%)$ \\
\hline Control & $96 \mathrm{c}$ & $71 \mathrm{c}$ \\
\hline \multicolumn{3}{|l|}{ Phosphorous acid - 7.49 kg a.i./ha } \\
\hline Initial bulking +2 weeks +2 weeks $\mathrm{x}$ & $29 \mathrm{a}$ & $7 \mathrm{a}$ \\
\hline 2 weeks after initial bulking +2 weeks +2 weeks $^{y}$ & $42 \mathrm{ab}$ & $22 \mathrm{a}$ \\
\hline 4 weeks after initial bulking +2 weeks + weeks ${ }^{z}$ & $67 \mathrm{~b}$ & $41 \mathrm{~b}$ \\
\hline \multicolumn{3}{|l|}{ Phosphorous acid - $9.37 \mathrm{~kg}$ a.i./ha } \\
\hline Initial bulking +2 weeks +2 weeks $^{x}$ & $33 \mathrm{a}$ & $11 \mathrm{a}$ \\
\hline 2 weeks after initial bulking +2 weeks +2 weeks $y$ & $21 \mathrm{a}$ & $12 \mathrm{a}$ \\
\hline 4 weeks after initial bulking +2 weeks +2 weeks $^{\mathrm{z}}$ & $46 \mathrm{ab}$ & $20 \mathrm{a}$ \\
\hline
\end{tabular}

${ }^{w}$ Mean of four replicates and six tubers per replicate. Means within the same column followed by the same letter are not significantly different at $P=0.05$, according to Fisher's protected least significant difference test.

${ }^{x}$ Initial application on 8 July.

${ }^{\mathrm{y}}$ Initial application on 22 July.

${ }^{\mathrm{z}}$ Initial application on 6 August.

Table 5. Mean incidence and severity of rot on tubers inoculated with either Phytophthora erythroseptica or Pythium ultimum after potato foliage was treated with phosphorous acid in the field at Othello, WA, Mount Vernon, WA, and Bonners Ferry, ID in 2002; and in Aberdeen, ID in $2003^{y}$

\begin{tabular}{|c|c|c|c|c|}
\hline \multirow[b]{2}{*}{ Location, treatment } & \multicolumn{2}{|c|}{ Incidence } & \multicolumn{2}{|c|}{ Severity } \\
\hline & $\begin{array}{c}\text { Pink } \\
\text { rot }\end{array}$ & $\begin{array}{c}\text { Pythium } \\
\text { leak }\end{array}$ & $\begin{array}{c}\text { Pink } \\
\text { rot }\end{array}$ & $\begin{array}{c}\text { Pythium } \\
\text { leak }\end{array}$ \\
\hline \multicolumn{5}{|l|}{ Othello } \\
\hline \multicolumn{5}{|c|}{ Ranger Russet and Umatilla Russet combined ${ }^{\mathrm{z}}$} \\
\hline Nontreated control & 99 & 20 & $85 \mathrm{~b}$ & 10 \\
\hline Two applications at $9.37 \mathrm{~kg}$ a.i./ha & 99 & 23 & $69 \mathrm{a}$ & 11 \\
\hline Three applications at $9.37 \mathrm{~kg}$ a.i./ha & 92 & 20 & $57 \mathrm{a}$ & 11 \\
\hline \multicolumn{5}{|c|}{ Mount Vernon } \\
\hline \multicolumn{5}{|c|}{ White Rose and Umatilla Russet combined ${ }^{\mathrm{z}}$} \\
\hline Nontreated control & $100 \mathrm{~b}$ & 41 & $87 \mathrm{c}$ & 40 \\
\hline Two applications at $9.37 \mathrm{~kg}$ a.i./ha & $96 \mathrm{~b}$ & 42 & $52 \mathrm{~b}$ & 42 \\
\hline Three applications at $9.37 \mathrm{~kg}$ a.i./ha & $88 \mathrm{a}$ & 46 & $40 \mathrm{a}$ & 45 \\
\hline \multicolumn{5}{|l|}{ Bonners Ferry } \\
\hline \multicolumn{5}{|c|}{ Russet Burbank and Russet Norkotah combined ${ }^{\mathrm{z}}$} \\
\hline Nontreated control & 94 a & $\ldots$ & 45 & $\ldots$ \\
\hline Two applications at $9.37 \mathrm{~kg}$ a.i./ha & $85 \mathrm{ab}$ & $\ldots$ & 34 & $\ldots$ \\
\hline Three applications at $9.37 \mathrm{~kg}$ a.i./ha & $80 \mathrm{~b}$ & $\ldots$ & 27 & $\ldots$ \\
\hline \multicolumn{5}{|l|}{ Aberdeen } \\
\hline \multicolumn{5}{|l|}{ Russet Norkotah } \\
\hline Nontreated control & $84 \mathrm{a}$ & $\ldots$ & 20 & $\ldots$ \\
\hline Three applications at $9.37 \mathrm{~kg}$ a.i. $/ \mathrm{ha}$ & $66 \mathrm{~b}$ & $\ldots$ & 16 & $\ldots$ \\
\hline
\end{tabular}

${ }^{y}$ Mean of four replicates and 10 tubers per replicate. Means within the same column and within a location followed by the same letter are not significantly different at $P=0.05$, according to Fisher's protected least significant different test; $\ldots=$ not included in test.

${ }^{\mathrm{z}}$ Cultivars are combined because of no significant $(P=0.05)$ cultivar-treatment interaction. 
tions of Umatilla are rare even though the foliage is susceptible to late blight. Consequently, applications of phosphorous acid on Umatilla may be warranted only during conditions favoring severe late blight, and one or two applications rather than three may be sufficient for management. In contrast, late blight tuber rot is likely to be reduced in the field with two to three applications of phosphorous acid on the susceptible cultivars commonly grown in the Pacific Northwest.

Direct comparisons between the US- 8 and US-11 isolates cannot be made in this study due to differences in inoculation procedures. Tubers inoculated with the US-11 isolate were wounded, whereas those inoculated with the US- 8 isolate were not wounded in 2002. When wounding was employed for inoculation with the US-11 isolate, high incidence of disease occurred, and ranged from 52 to $100 \%$ for the treatments and 87 to $100 \%$ for the nontreated controls. In 2003, challenge inoculations using the US-11 isolate without wounding showed significant disease reduction in tubers by phosphorous acid applications. Disease incidence ranged from 10 to $30 \%$ for the phosphorous acid treatments and was $80 \%$ for the nontreated control.

Suppression of pink rot with phosphorous acid was not as remarkable as suppression of late blight during the 3 years of the study. Significant reductions in pink rot incidence were observed for tubers from Mount Vernon, Bonners Ferry, and Aberdeen, but not from Othello in 2002. The percentage of reduction in disease incidence was relatively small, and three applications were required to obtain disease suppression at Mount Vernon and Bonners Ferry (Table 5). The inoculation technique employed for tubers grown at Othello and Mount Vernon was rigorous, with tubers being artificially wounded. Tubers were not wounded at Bonners Ferry in 2002 or Aberdeen in 2003, where tubers were either dip or filter disc inoculated instead, and significant reductions in pink rot incidence were observed, even though rot severity did not differ among treatments. Results in 2003 at Mount Vernon, where a different inoculation procedure was used, were more favorable for pink rot control. Instead of wounding or submerging half of the tuber in a zoospore suspension, zoospore inoculum was placed directly on the stem end and one eye of each tuber. In this case, the $9.37 \mathrm{~kg}$ a.i./ha rate applied at initial bulking effectively reduced incidence and severity of pink rot. However, in a study in Australia where nonwounded tubers were grown in artificially infested soil in pots, pink rot control by phosphorous acid was not effective (31). In a study in Ireland, phosphorous acid also was not promising (6) but, again, wounded tubers inoculated with $P$. erythroseptica were used. Infection of tubers by $P$. erythrosep- tica generally occurs via stolons, although tubers also can be infected by zoospores through the eyes and wounds (27). Phosphorous acid generally may be a more effective chemical for pink rot control when infections occur by natural openings, stolons, or roots, rather than wounds, but further studies are needed to identify specific conditions that limit its effectiveness.

In this study, inoculum densities for laboratory assays were selected based on a sporangia or zoospore concentration that provided consistently high levels of infection. Pink rot inoculations of tubers from nontreated plots resulted in $84 \%$ incidence or higher even when tubers were not wounded. This level of disease pressure is almost never observed in commercial potato fields exposed to natural late blight epidemics in the Pacific Northwest. As a result, the ability to show disease reduction at extremely elevated disease levels in lab assays may not correlate well with disease reductions realized when infection occurs naturally. The inoculation method used in 2003 trials was less invasive than wounding, used less inoculum than dipping, and resulted in a significant reduction in pink rot severity for all $9.37 \mathrm{~kg}$ a.i. timings. Presumably, the dip-inoculation method may not have precluded infection routes provided by wounds. If the stem-end-andeye inoculation method is a better measure of pink rot potential, a stronger case could be made for using phosphorous acid for pink rot control. More work comparing different inoculation techniques needs to be done.

Pythium leak was not controlled with phosphorous acid in this study. Wounding of tubers after harvest was used for all inoculations because this pathogen generally is regarded as opportunistic and incapable of penetrating the undamaged skin of a potato tuber (27). Wound inoculation procedures may underestimate product performance in the field, and wounding of the tuber periderm does circumvent some of the natural defenses of the tuber. It is not known how foliar applications of phosphorous acid contribute to tuber protection. Applications of phosphorous acid in citrus trees resulted in an elevated production of scoparone, a phytoalexin that has been demonstrated to be inhibitory to Phytophthora citrophthora infection (1). Scoparone accumulates in citrus bark after pathogen invasion. If a similar phytoalexin accumulates in the potato periderm, a wound inoculation may circumvent any defense response initiated by phosphorous acid. More research is needed in potato on the potential stimulation of host defense mechanisms by phosphorous acid for tuber protection.

In this study, tubers were challenge inoculated after harvest. Even though these three diseases occur commonly during the storage season, they often occur in the field before the time of harvest. Whether or not the same results would be obtained for infections occurring on tubers in the field rather than in storage is not known at this time. Pink rot incidence in field studies relying on natural infection often is lower than in commercial fields; thus, it is difficult to adequately evaluate potential disease control measures under such situations. Studies to evaluate the required length of time between foliar application and tuber protection still are needed.

Phosphorous acid treatments usually were not associated with an increase in tuber yield in this study. Yield was increased significantly at Aberdeen in 2003, perhaps because an undetected root pathogen was controlled at that particular location, but this is speculative.

Late blight tuber rot and pink rot likely will be reduced in the field under conditions favoring tuber rots with applications of phosphorous acid on the susceptible cultivars planted in the Pacific Northwest. However, sound cultural practices such as avoiding over-irrigation of fields or areas in fields where excess water may accumulate, in addition to fungicide applications, also are critical for managing potato tuber rots caused by oomycetes in the Pacific Northwest (18).

\section{ACKNOWLEDGMENTS}

We thank T. Cummings, B. Gundersen, L. Porter, and A. Schneider for technical assistance.

\section{LITERATURE CITED}

1. Afek, U., and Sztenjberg, A. 1989. Effects of fosetyl-Al and Phosphorous acid on scoparone, a phytoalexin associated with resistance of citrus to Phytophthora citrophthora. Phytopathology 79:736-739.

2. Barrett, S. R., Shearer, B. L., and Hardy, G. E. St J. 2003. The efficacy of phosphite applied after inoculation on the colonization of Banksia brownii stems by Phytophthora cinnamomi. Australas. Plant Pathol. 32:1-7.

3. Coffey, M. D. 1987. Phytophthora root rot of avocado: An integrated approach to control in California. Plant Dis. 71:1046-1052.

4. Cohen, Y., and Coffey, M. D. 1986. Systemic fungicides and the control of oomycetes. Annu. Rev. Phytopathol. 24:311-338.

5. Cooke, L. R., and Little, G. 1996. Foliar application of phosphonate formulations for the control of potato tuber blight. Brighton Crop Prot. Conf. Pests Dis. 1:263-268.

6. Cooke, L. R., and Little, G. 2001. The effect of foliar application of phosphonate formulations on the susceptibility of potato tubers to late blight. Pest Manage. Sci. 58:17-25.

7. Derie, M. L., and Inglis, D. A. 2001. Persistence of complex virulences in populations of Phytophthora infestans in Western Washington. Phytopathology 91:606-612.

8. Dunstan, R. H., Smillie, R. H., and Grant, B. R. 1990. The effects of sub-toxic levels of phosphonate on the metabolism and potential virulence factors of Phytophthora palmivora. Physiol. Mol. Plant Pathol. 36:205-220.

9. Erwin, D. C., and Ribeiro, O. K. 1996. Phytophthora Diseases Worldwide. American Phytopathological Society Press, St. Paul, MN.

10. Fenn, M. E., and Coffey, M. D. 1989. Quantification of phosphonate and ethyl phosphonate in tobacco and tomato tissues and significance for the mode of action of two phosphonate fungicides. Phytopathology 79:76-82.

11. Forster, H., Adaskaveg, J. E., Kim, D. H., and 
Stanghellini, M. E. 1998. Effect of phosphite on tomato and pepper plants and on susceptibility of pepper to Phytophthora root and crown rot in hydroponic culture. Plant Dis. 82:1165-1170.

12. Guest, D., and Bompeix, G. 1990. The complex mode of action of phosphonates. Australas. Plant Pathol. 19:113-114.

13. Guest, D., and Grant, B. R. 1991. The complex mode of action of phosphonates as antifungal agents. Biol. Rev. 66:159-187.

14. Hamm, P. B., Inglis, D. A., Finn, R., and Olaya, G. 2004. Resistance to mefenoxam in isolates of Pythium ultimum from potato in Oregon. Am. J. Pot. Res. 81:64.

15. Inglis, D. A., Johnson, D. A., Legard, D. E., Fry, W. E., and Hamm, P. B. 1996. Relative resistances of potato clones in response to new and old populations of Phytophthora infestans. Plant Dis. 80:575-578.

16. Johnson, D. A., Cummings, T. F., and Hamm, P. B. 2000. Cost of fungicides used to manage potato late blight in the Columbia Basin: 1996 to 1998. Plant Dis. 84:399-402.

17. Johnson, D. A., Cummings, T. F., Hamm, P. B., Rowe, R. C., Miller, J. S., Thornton, R. E., Pelter, G. Q., and Sorensen, E. J. 1997. Potato late blight in the Columbia Basin: An economic analysis of the 1995 epidemic. Plant Dis. 81:103-106.

18. Johnson, D. A., Martin, M., and Cummings, T. F. 2003. Effect of chemical defoliation, irri- gation water, and distance from the pivot on late blight tuber rot in center-pivot irrigated potatoes in the Columbia Basin. Plant Dis. 87:977-982.

19. Miller, J. S., Cummings, T. F., Mikitzel, L. J., and Johnson, D. A. 2002. Influence of timing of harvest in relation to haulm killing and planting date on potato tuber rot caused by Phytophthora infestans. Plant Dis. 86:264-268.

20. Miller, J. S., Hamm, P. B., and Johnson, D. A. 1997. Characterization of the Phytophthora infestans population in the Columbia Basin of Oregon and Washington from 1992 to 1994. Phytopathology 87:656-660.

21. Miller, J. S., and Johnson, D. A. 2000. Competitive fitness of Phytophthora infestans isolates under semiarid field conditions. Phytopathology 90:220-227.

22. Mulrooney, R. P. 1982. Evaluation of Ridomil for pink rot and leak control, 1981. Fungic. Nematicide Test 37:78.

23. Ouimette, D. G., and Coffey, M. D. 1989. Comparative antifungal activity of four phosphonate compounds against isolates of nine Phytophthora species. Phytopathology 79:761767.

24. Ouimette, D. G., and Coffey, M. D. 1989. Phosphonate levels in avocado (Persea americana) seedlings and soil following treatment with fosetyl-Al or potassium phosphonate. Plant Dis. 73:212-215.

25. Porter, L. D., Inglis, D. A., and Johnson, D. A.
2004. Identification and characterization of resistance to Phytophthora infestans in leaves, stems, flowers, and tubers of potato clones in the Pacific Northwest. Plant Dis 88:965-972.

26. Porter, L. D., Johnson, D. A., and Cummings, T. F. 2001. Development of Phytophthora infestans in potato tubers of nine clones in storage. (Abstr.) Phytopathology 91:S188.

27. Salas, B., Secor, G. A., Taylor, R. J., and Gudmestad, N. C. 2003. Assessment of resistance of tubers of potato cultivars to Phy tophthora erythroseptica and Pythium ultimum. Plant Dis. 87:91-97.

28. Smillie, R., Grant, B. R., and Guest, D. 1989. The mode of action of phosphite: Evidence for both direct and indirect modes of action of three Phytophthora spp. in plants. Phytopathology 79:921-926.

29. Taylor, R. J., Salas, B., Secor, G. A., Rivera V., and Gudmestad, N. C. 2002. Sensitivity of North American isolates of Phytophthora erythroseptica and Pythium ultimum to mefenoxam (metalaxyl). Plant Dis. 86:797-802.

30. Torres, H., Martin, C., and Henfling, J. 1985. Chemical control of pink rot of potato (Phytophthora erythroseptica Pethyb.). Am. Potato J. 62:355-361.

31. Wicks, T. J., Davoren, C. W., and Hall, B. H. 2000. Fungicidal control of Phytophthora erythroseptica: The cause of pink rot on potato. Am. J. Potato Res. 77:233-240. 